\title{
ATP and Energy Charge as Criteria of Growth and Metabolic Activity of Mollicutes: Application to Spiroplasma citri
}

\author{
By P. H. M. SAGLIO* AND M. J. DANIELS \\ John Innes Institute, Colney Lane, Norwich NR4 $7 U H$ \\ AND A. PRADET \\ Laboratoire de Physiologie Végétale, I.N.R.A., Centre de Recherches de Bordeaux, \\ 33140 Pont-de-la-Maye, France
}

(Received 7 July 1978)

\begin{abstract}
Intracellular ATP concentrations and energy charge were monitored during the growth of Spiroplasma citri and related to the number of colony-forming units, to the $\mathrm{pH}$ of the medium and to incorporation of radioactive precursors. Of three different methods used for extracting nucleotides - trichloroacetic acid, perchloric acid and boiling Tris $/ \mathrm{H}_{2} \mathrm{SO}_{4}$ buffer - the trichloroacetic acid treatment was the most effective. During the active growth phase the ATP concentration increased exponentially, in the same way as other growth parameters. However, as soon as the metabolic activity slowed down, there was a rapid drop of ATP concentration and of total adenylate content, which was followed much later by a parallel decrease in the number of colony-forming units. During active growth, energy charge remained at around 0.9 and decreased only slowly during the stationary phase. Incorporation of labelled thymidine or phenylalanine followed a different pattern during the late phase of the culture and gave less information concerning the viability of the organisms.
\end{abstract}

\section{INTRODUCTION}

The methods available for measuring the growth of Mollicutes are limited and not always very suitable. In practice, only two standard methods give accurate results: (i) serial dilution followed by plating out, a sensitive, but time consuming method, and (ii) monitoring the incorporation of radioactive material into the culture (Saglio et al., 1973). The latter method is very simple and quick but does not discriminate between viable and non-viable organisms, which the former procedure does.

The difficulties encountered when using other bacteriological techniques for measuring growth of Mollicutes have been summarized by Windsor \& Boarer (1972) who described a rapid enumeration method based on the assessment of lactate dehydrogenase. The method is, of course, limited to organisms containing this enzyme and cannot detect less than $10^{7}$ organisms $\mathrm{ml}^{-1}$.

For these reasons another criterion was sought to measure the growth of Mollicutes. namely ATP concentration. Study of ATP content as a growth criterion is facilitated by using the highly specific and very sensitive bioluminescent reaction of luciferase. Measurements of ATP level can be complemented with those of AMP and ADP, which allows the energy charge $\left[\left(\mathrm{ATP}+\frac{1}{2} \mathrm{ADP}\right) /(\mathrm{ATP}+\mathrm{ADP}+\mathrm{AMP})\right]$ to be calculated (Atkinson, 1968;

* Present address: Laboratoire de Physiologie Végétale, I.N.R.A., Centre de Recherches de Bordeaux, 33140 Pont-de-la-Maye, France. 
Bomsel \& Pradet, 1968). This method has been used for several years as a biomass criterion in fields such as oceanography (Holm-Hansen, 1969), soil microbiology (MacLeold et al., 1969) and in bacteriology where it is useful in studying metabolic adaptation to different environmental conditions (see Niven et al., 1977; Knowles, 1977). To check the validity of this method for measuring the growth of Mollicutes, we have measured the ATP level and energy charge during the growth of batch cultures of Spiroplasma citri, together with other indicators of growth such as $\mathrm{pH}$ of the medium, number of colony-forming units (c.f.u.) and incorporation of radioactive material into the acid-insoluble fraction of the cells. A preliminary account of some of these results has appeared (Saglio et al., 1976).

\section{METHODS}

Organism and culture medium. Spiroplasma citri, strain Israeli, NCPPB 2565 (Daniels et al., 1973) was cultivated in a medium containing (per litre): $200 \mathrm{ml}$ foetal calf serum inactivated by heating at $60^{\circ} \mathrm{C}$ for $30 \mathrm{~min}, 21 \mathrm{~g}$ PPLO broth (Difco), $1 \mathrm{~g}$ glucose, $1 \mathrm{~g}$ fructose, $2 \mathrm{~g}$ sucrose and $70 \mathrm{~g}$ sorbitol; the $\mathrm{pH}$ was adjusted to 7.6 with $\mathrm{KOH}$. Solid medium contained $1 \%(\mathrm{w} / \mathrm{v})$ Bacto-agar (Difco). Cultures were incubated at $32{ }^{\circ} \mathrm{C}$.

Fresh culture medium $(100 \mathrm{ml})$ was inoculated with $1 \mathrm{ml}$ of an actively growing suspension of $S$. citri. After mixing, $4.75 \mathrm{ml}$ of seeded medium was added to two tubes containing $0.25 \mathrm{ml}$ of either $\left[{ }^{3} \mathrm{H}\right]$ phenylalanine $\left(100 \mu \mathrm{Ci} \mathrm{ml}^{-1}, 20 \mathrm{Ci} \mathrm{mmol}^{-1}\right)$ or $\left[\mathrm{U}_{-}{ }^{14} \mathrm{C}\right]$ thymidine $\left(10 \mu \mathrm{Ci} \mathrm{ml}^{-1}, 62 \mathrm{mCi} \mathrm{mmol}{ }^{-1}\right.$; both from The Radiochemical Centre, Amersham). Water $(9.5 \mathrm{ml})$ was added to the remaining $90.5 \mathrm{ml}$ medium to give the same dilution as the radioactive samples. The non-radioactive culture was used for plating and ATP measurement.

Measurement of incorporated radioactivity. Samples $(100 \mu \mathrm{l})$ of culture were added to $2 \mathrm{ml}$ of ice-cold $5 \%$ $(\mathrm{w} / \mathrm{v})$ trichloroacetic acid (TCA). After $5 \mathrm{~min}$ in ice, the material was filtered through glass fibre discs (Whatman GF/C, $2.5 \mathrm{~cm}$ diam.), using three rinses of cold $5 \%$ TCA to collect all the precipitate. The filter was finally washed with acetone and dried. The dry filters were each immersed in $2 \mathrm{ml}$ toluene [containing 2-(4'-tert-butylphenyl)-5-(4"-biphenylyl)-1,3,4-oxadiazole (Ciba) at $5 \mathrm{~g} \mathrm{l}^{-1}$ ] and radioactivity was measured in a scintillation counter. All determinations were done in triplicate. Using this technique, the acid-insoluble precipitate of a sample of uninoculated medium gave an average of $50 \mathrm{c} . \mathrm{p} . \mathrm{m}$. regardless of the nature of the labelled precursor.

Plating. Diluted $S$. citri culture $(10 \mu \mathrm{l})$ was plated on culture medium solidified with $1 \%(\mathrm{w} / \mathrm{v})$ agar and incubated at $32{ }^{\circ} \mathrm{C}$ for $8 \mathrm{~d}$. The colonies, stained with a $5 \%$ (v/v) ethanolic solution of Dienes' stain (Difco), were counted with a stereo dissecting microscope.

Preparation of samples for luciferase assay. The organisms from $1 \mathrm{ml}$ culture were quickly harvested by vacuum filtration on a GS Millipore membrane (pore size $0.22 \mu \mathrm{m}, 13 \mathrm{~mm}$ diam.), which traps more than $99 \%$ of the cells (Saglio et al., 1973). Immediately after filtration the free nucleotides were extracted using one of the following methods. All the extractions were done in triplicate. The whole of each operation took less than $10 \mathrm{~s}$.

1. Trichloroacetic acid treatment. Each filter was dipped in $1 \mathrm{ml}$ of cold TCA $(5 \%$, w/v) for $20 \mathrm{~min}$. The acid was then removed by three successive extractions with 4 volumes of water-saturated ether. After traces of ether had been eliminated by bubbling with air, the $\mathrm{pH}$ was carefully adjusted to 7.5 and the volume to $2 \mathrm{ml}$. The samples were kept frozen until assayed.

2. Perchlorate treatment. Each filter was dipped in $0.5 \mathrm{M}-\mathrm{HClO}_{4}(1 \mathrm{ml})$ for $15 \mathrm{~min}$ at room temperature. The extracts were neutralized with about $0.25 \mathrm{ml} 2 \mathrm{M}-\mathrm{KOH}$ and the volume was adjusted to $2 \mathrm{ml}$ with $0.05 \mathrm{M}$ Tris $/ \mathrm{H}_{2} \mathrm{SO}_{4}$ buffer $(\mathrm{pH} 7 \cdot 5)$. The precipitate was removed by centrifugation and the supernatant was kept frozen until assayed.

3. Hot Tris buffer treatment. Each filter was immersed in $0.9 \mathrm{ml}$ hot (about $90{ }^{\circ} \mathrm{C}$ ) $0.05 \mathrm{M}$-Tris $/ \mathrm{H}_{2} \mathrm{SO}_{4}$ buffer ( $\mathrm{pH} 7.5)$ in a screw-capped vial and left for $5 \mathrm{~min}$ at $100^{\circ} \mathrm{C}$ for nucleotide extraction. The vials were then cooled and the extracts were kept frozen until assayed.

Preparation of firefly lantern extract. $\mathrm{MgSO}_{4} .7 \mathrm{H}_{2} \mathrm{O}(100 \mathrm{mg})$ and firefly tails $(100 \mathrm{mg}$; Sigma) were ground together in a mortar at $0{ }^{\circ} \mathrm{C}$ with $1 \mathrm{ml} 0.1 \mathrm{M}-\mathrm{Na}_{2} \mathrm{HAsO}_{4}(\mathrm{pH} 7.5)$. A further $9 \mathrm{ml} \mathrm{Na} \mathrm{HAsO}_{4}$ was added to the paste to bring the volume to $10 \mathrm{ml}$. The suspension was clarified by centrifugation $(17000 \mathrm{~g} ; 10 \mathrm{~min}$; $4{ }^{\circ} \mathrm{C}$ ). The supernatant was left at $4{ }^{\circ} \mathrm{C}$ overnight to allow the endogenous ATP to be destroyed and then stored in $1 \mathrm{ml}$ portions at $-20^{\circ} \mathrm{C}$ until required. Immediately before use, portions were thawed, centrifuged $\left(1000 \mathrm{~g} ; 5 \mathrm{~min} ; 4^{\circ} \mathrm{C}\right)$ to remove any precipitate, and kept in ice throughout the assay.

Luciferase assays. Samples $(0.3 \mathrm{ml})$ were added to $1 \mathrm{ml}$ disposable polystyrene test tubes and equilibrated to room temperature. A sample tube was placed in the reaction chamber of a Pico-ATP biophotometer 
(Jobin et Yvon, Longjumeau, France) which was coupled to a chart recorder. ATP content was deduced from the height of the peak of luminescence produced after adding $50 \mu \mathrm{l}$ of firefly lantern extract from a pneumatic syringe.

ADP and AMP were first converted to ATP according to the procedure of Pradet (1967) except that adenylate kinase and pyruvate kinase, which are stored as precipitates in ammonium sulphate solution, were centrifuged just before use in order to remove the salt which might otherwise interfere with the reaction. These nucleotides were then determined by difference.

Internal standardization was used in all ATP determinations and the instrument was also calibrated with ATP solutions of known concentrations.

When the scintillation counter was used, cold firefly extract $(100 \mu \mathrm{l})$ was added with an automatic pipette to the sample $(0.9 \mathrm{ml})$ contained in the scintillation vial previously brought to room temperature. After quickly mixing, the open vial was placed in the scintillation chamber for counting. The whole operation, from the addition of the enzyme to the start of the counting, was quite reproducible and lasted less than $10 \mathrm{~s}$.

\section{RESULTS}

\section{Conditions of fixation and extraction}

The different procedures for extracting nucleotides from an actively growing suspension of $S$. citri are compared in Table 1 . The rapidity of the fixation is indicated by the fraction ATP/(ATP + ADP + AMP) and by the energy charge. The presumably very fast conversion of ATP to ADP and AMP in unfixed cells exposed to unfavourable conditions should lower the value of these two parameters when fixation is not instantaneous. Fixation in TCA and $\mathrm{HClO}_{4}$ gave similar values, which were significantly higher than those obtained by fixation in boiling Tris $/ \mathrm{H}_{2} \mathrm{SO}_{4}$. However, the boiling Tris/ $\mathrm{H}_{2} \mathrm{SO}_{4}$ buffer method gave the highest values for the quality and efficiency of the extraction, indicated by the sum of nucleotides (ATP + ADP + AMP). This result could be explained by losses due to the numerous operations needed in the $\mathrm{HClO}_{4}$ and TCA treatments. The $\mathrm{HClO}_{4}$ extract contained more ATP than the Tris $/ \mathrm{H}_{2} \mathrm{SO}_{4}$ and TCA extracts because this method gave very little hydrolysis and a better extraction yield than TCA.

\section{Influence of $\mathrm{pH}$ on the bioluminescent reaction}

A range of $\mathrm{pH}$ was obtained by adding dilute $\mathrm{H}_{2} \mathrm{SO}_{4}$ to $0.05 \mathrm{M}$-Tris $/ \mathrm{H}_{2} \mathrm{SO}_{4}$ buffer ( $\mathrm{pH}$ $8 \cdot 4$ ). With 10 pmol ATP, there was a rapid increase in the counts recorded in the scintillation counter as the $\mathrm{pH}$ was increased from $7 \cdot 0$ to $7 \cdot 4$. Maximum light emission occurred between $\mathrm{pH} \mathrm{7.4} \mathrm{and} \mathrm{7.6,} \mathrm{and} \mathrm{decreased} \mathrm{again} \mathrm{as} \mathrm{the} \mathrm{pH}$ was increased to 8.4 . The counts recorded at $\mathrm{pH} 7.8$ and 7.2 or $\mathrm{pH} 8.2$ and 7.0 represented, respectively, only 82 and $68 \%$ of those recorded at $\mathrm{pH} 7.5$ [9300 counts $\left.(0.5 \mathrm{~min})^{-1}\right]$.

\section{Use of liquid scintillation counter}

The counts recorded by the scintillation counter in response to light emitted by the reaction mixture increased in proportion to the square of the ATP concentration (Fig. 1; see Kimmich et al., 1975, for a detailed discussion of this relationship). Unlike the results of Schram (1970), this relationship was not affected by the length of time which elapsed between adding the firefly extract and starting the counting or by the counting period itself. In some experiments, not reported here, the same relationship was observed with concentrations of ATP up to $80 \mathrm{pmol} \mathrm{ml}^{-1}$.

For a given concentration of ATP, the counts recorded by the scintillation counter also increased linearly with the square of the concentration of firefly extract added to the sample. In this experiment $10 \mathrm{pmol}$ ATP in $0.9 \mathrm{ml} 0.05 \mathrm{M}$-Tris $/ \mathrm{H}_{2} \mathrm{SO}_{4}(\mathrm{pH} 7.5)$ gave 6205 counts $(0.5 \mathrm{~min})^{-1}$ when $0.1 \mathrm{ml}$ firefly extract was added. 


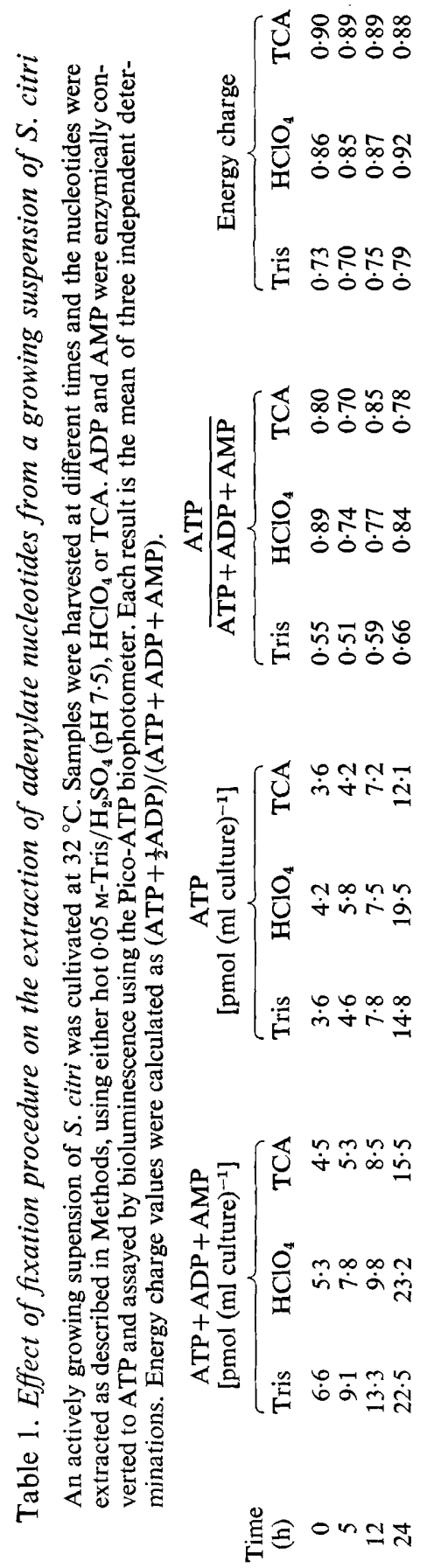




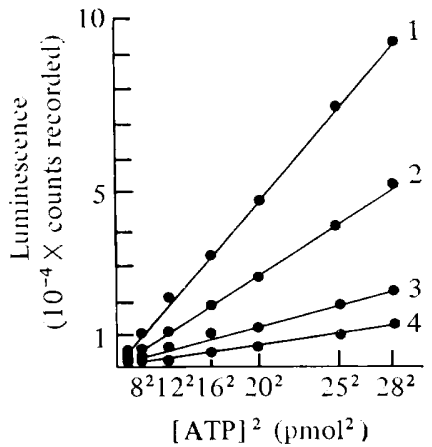

Fig. 1

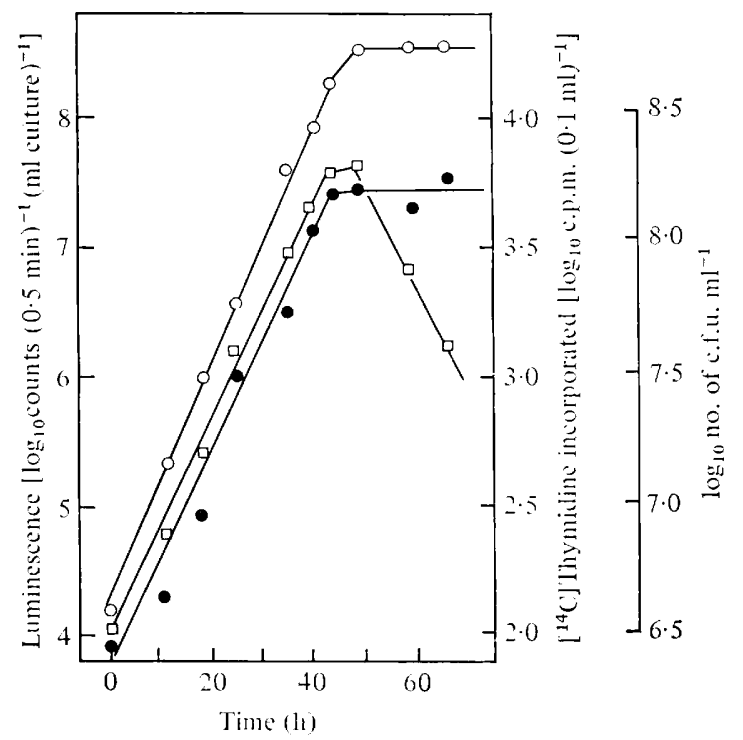

Fig. 2

Fig. 1. Response of the liquid scintillation counter to increasing concentration of ATP. The period of counting and the length of time which elapsed between adding the firefly extract and starting the counting itself were, respectively: (1) $1 \mathrm{~min}$ and $65 \mathrm{~s}$; (2) $0.5 \mathrm{~min}$ and $30 \mathrm{~s}$; (3) $0.2 \mathrm{~min}$ and $15 \mathrm{~s}$; (4) $0.1 \mathrm{~min}$ and $5 \mathrm{~s}$. Each point is the mean of three independent determinations. Under the same conditions, control vials without ATP gave 300 counts $(0 \cdot 5 \mathrm{~min})^{-1}$.

Fig. 2. Growth curves of $S$. citri in liquid medium: $\bigcirc$, incorporated $\left[{ }^{14} \mathrm{C}\right]$ thymidine; $\bullet$, number of colony-forming units; $\square$, ATP extracted by hot $0.05 \mathrm{M}$-Tris $/ \mathrm{H}_{2} \mathrm{SO}_{4}(\mathrm{pH} \mathrm{7.5)}$ and assayed by bioluminescence using a liquid scintillation counter. In this experiment, $10 \mathrm{pmol}$ ATP and controls without ATP gave, respectively, 14188 and 510 counts $(0.5 \mathrm{~min})^{-1}$. Each point is the mean of three independent determinations.

\section{Growth measurement}

The growth of $S$. citri in liquid medium was measured simultaneously by the following methods: incorporation of radioactive material into the acid-insoluble precipitate; number of c.f.u. $\mathrm{ml}^{-1}$ on solid medium; $\mathrm{pH}$ of the medium; concentrations of adenylic nucleotides, determined using either the liquid scintillation counter (Fig. 2) or the Pico-ATP biophotometer (Fig. 3).

The incorporation of either $\left[{ }^{14} \mathrm{C}\right]$ thymidine or $\left[{ }^{3} \mathrm{H}\right]$ phenylalanine was exponential during the first $43 \mathrm{~h}$ (Fig. 2) or $50 \mathrm{~h}$ (Fig. $3 \mathrm{a}$ ). It then slowed down, and reached a maximum value which was maintained indefinitely. There was no evidence of any hydrolysis of the macromolecules into which the radioactive material has been incorporated.

When the numbers of c.f.u. were measured, growth followed the same exponential curve during the first $43 \mathrm{~h}$ (Fig. 2) or $50 \mathrm{~h}$ (Fig. $3 a$ ). It then slowed down to reach a short plateau (from 69 to $93 \mathrm{~h}$ ) followed by a very sharp exponential decrease in titre, which dropped from $8 \times 10^{8}$ to $2 \times 10^{4}$ c.f.u. $\mathrm{ml}^{-1}$ in $70 \mathrm{~h}$.

During the growth of $S$. citri, there was a strong fermentation of sugars with the production of lactic acid which lowered the $\mathrm{pH}$ of the medium (Fig. $3 a$ ). Starting from $\mathrm{pH} 7 \cdot 5$, the $\mathrm{pH}$ decreased slowly until the titre reached about $10^{8} \mathrm{c}$.f.u. $\mathrm{ml}^{-1}$. Then there was a very rapid fall of $\mathrm{pH}$ which stabilized around 4.8 when active growth ended.

The ATP concentration per cell remained constant during the exponential phase, its concentration in the culture medium increasing in proportion to the cell number (Fig. 2). However, as soon as metabolic activity slowed down, there was a dramatic exponential 


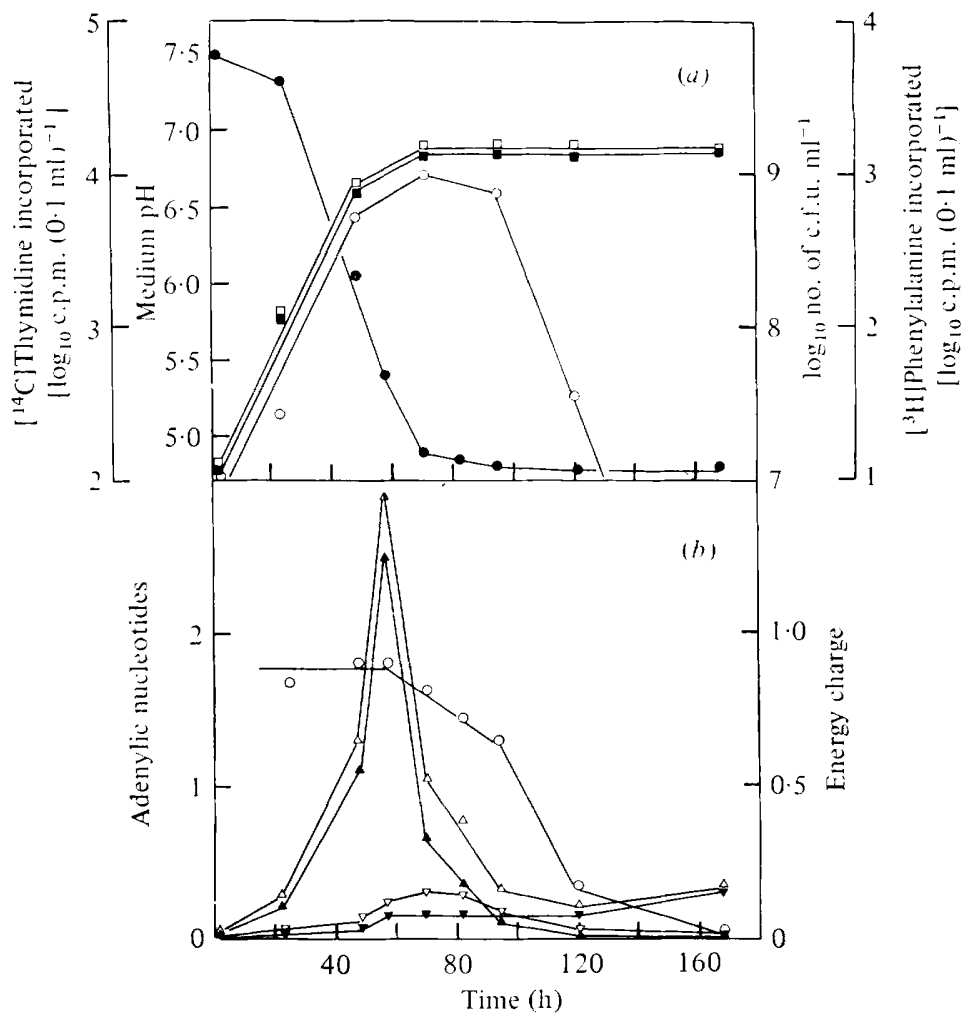

Fig. 3. Comparison of the behaviour of various parameters during batch culture of $S$. citri at $32{ }^{\circ} \mathrm{C}$. (a) $\mathrm{O}$, Number of colony-forming units; $\mathrm{pH}$ of the medium; $\square$, incorporated $\left[{ }^{14} \mathrm{C}\right]-$ thymidine $\left(0.5 \mu \mathrm{Ci} \mathrm{ml}^{-1}\right) ; \boldsymbol{\square}$, incorporated [ $\left.{ }^{3} \mathrm{H}\right]$ phenylalanine $\left(5 \mu \mathrm{Ci} \mathrm{ml}^{-1}\right)$. (b) $\triangle$, Total adenylates; $\Delta$, ATP; $\nabla$, ADP; $\nabla$, AMP [all expressed as nmol (ml culture) ${ }^{-1}$ ]; $O$, energy charge. The adenylic nucleotides were extracted by hot $0.05 \mathrm{M}-\mathrm{Tris} / \mathrm{H}_{2} \mathrm{SO}_{4}(\mathrm{pH} \mathrm{7.5)}$ and assayed by bioluminescence, after conversion into ATP, using the Pico-ATP biophotometer. Each point is the mean value of three independent determinations, except for the $\mathrm{pH}$ values which were measured only once at each time.

drop in ATP concentration; this began $38 \mathrm{~h}$ before the number of c.f.u. showed a similar decrease (Fig. 3).

In contrast, the concentration of AMP remained low and extremely stable throughout the experiment, especially during the stationary phase which corresponded to the rapid breakdown of ATP (Fig. $3 b$ ). It increased only slowly at the end of the incubation time.

The total adenylate content followed a pattern similar to ATP (Fig. 3b). After an exponential increase corresponding to the active growth phase and a very sharp decrease during the stationary phase, it tended to stabilize and even to increase slightly during the decline phase of the culture.

The energy charge (Fig. $3 b$ ) remained relatively constant with values close to 0.9 throughout the exponential growth phase. During the stationary phase, the very sharp decrease in the total nucleotides pool, which paralleled the breakdown of ATP, tended to maintain the energy charge at high values which decreased only slowly from 0.9 to 0.65 . In contrast, the decline phase was characterized by a rapid drop of the energy charge value. 


\section{DISCUSSION}

For a precise measurement of energy metabolism, the TCA method was the preferred procedure though it was somewhat time-consuming. Although there were some losses of ATP during ether extraction of TCA, these were constant and did not change the values of the calculated energy charge. However, to estimate only the growth of $S$. citri, the hot Tris $/ \mathrm{H}_{2} \mathrm{SO}_{4}$ extraction method was the most satisfactory having the advantage of being extremely simple and quick.

The liquid scintillation counter method of assay was sufficiently sensitive to detect $S$. citri at $10^{6}$ c.f.u. $\mathrm{ml}^{-1}$, this being about 10 times better than other indirect methods for measuring growth. The Pico-ATP biophotometer was even more sensitive and could measure $0 \cdot 1$ pmol ATP and thus detect $S$. citri at less than $10^{5}$ c.f.u. $\mathrm{ml}^{-1}$. The sensitivity of the method might be even further increased using purified luciferin and luciferase preparations.

Spiroplasma citri, like many other organisms (Bomsel \& Pradet, 1968; Chapman et al., 1971; Niven et al., 1977), maintained its energy charge at high values close to 0.9 throughout active growth, though some eukaryotic organisms have been reported to have low energy charge values even when actively metabolizing (Edwards et al., 1975; Edwards \& Lloyd, 1977; Lloyd et al., 1978). The importance of energy charge as a metabolic regulator in vivo is still under debate (Atkinson, 1977; Fromm, 1977).

The simultaneous decrease of energy charge and total nucleotides, which often occurs in micro-organisms, was very pronounced with $S$. citri. Nothing is known about nucleotide catabolism in S. citri and one can only speculate that enzymes such as AMP-nucleosidase or AMP-deaminase, recently found in bacteria (Niven et al., 1977), are also involved in nucleotide catabolism in $S$. citri. As postulated by Chapman \& Atkinson (1973) and Schramm \& Leung (1973), these enzymes may, by decreasing the total adenylate pool size, help to stabilize the energy charge at values compatible with the maintenance of viability under conditions of environmental stress. However, intermediate values of energy charge are not always necessary to maintain viability; indeed, energy charge values as low as 0.15 occur in yeast under starvation (Ball \& Atkinson, 1975) and in germinating lettuce seeds (Bomsel \& Pradet, 1968) with no loss of viability.

As the ATP concentration in the culture remained strictly proportional to the number of cells during the active growing phase, it is an excellent growth parameter, as good as plating out or incorporation of radioactive material. However, after the exponential phase, incorporation of radioactive material, into either nucleic acids or proteins, was still maximal even though $99 \%$ of the organisms were by then dead. In contrast, the extremely sharp decrease of ATP as soon as the metabolic activity slowed down allowed one to determine very accurately the time when the exponential phase had ended. Knowledge of this point might be of great interest as a timer for physiological events.

P.H.M.S. is grateful to the Trustees of the John Innes Charity for a postdoctoral fellowship. We thank Mr Y. Danglot for his valuable technical help. 


\section{REFERENCES}

AtKInson, D. E. (1968). The energy charge of the adenylate pool as a regulatory parameter. Interaction with feedback modifiers. Biochemistry 7, 4030-4034.

AtKinson, D. E. (1977). Adenylate energy charge is a key factor. Trends in Biochemical Sciences 2, N198-N200.

Ball, W. J. JR. \& AtKinson, D. E. (1975). Adenylate energy charge in Saccharomyces cerevisiae during starvation. Journal of Bacteriology 121, 975-982.

Bomsel, J. L. \& Pradet, A. (1968). Study of adenosine-5'-mono, di and triphosphate in plant tissues. IV. Regulation of the level of nucleotides, in vivo, by adenylate kinase: theoretical and experimental studies. Biochimica et biophysica acta $\mathbf{1 6 2}$, 230-242.

Chapman, A. G. \& Atkinson, D. E. (1973). Stabilization of adenylate energy charge by the adenylate deaminase reaction. Journal of Biological Chemistry 248, 8309-8312.

Chapman, A. G., Fall, L. \& Atkinson, D. E. (1971). Adenylate energy charge in Escherichia coli during growth and starvation. Journal of Bacteriology 108, 1072-1085.

Daniels, M. J., Markham, P. G., Meddins, B. M., Plaskitt, A. K., Townsend, R. \& Bar-JosePh, M. (1973). Axenic culture of a plant pathogenic spiroplasma. Nature, London 244, 523-524.

Edwards, S. W. \& Lloyd, D. (1977). Changes in oxygen uptake rates, enzyme activities, cytochrome amounts and adenine nucleotide pool levels during growth of Acanthamoeba castellanit in batch cultures. Journal of General Microbiology 102, 135-144.

Edwards, C., Statham, M. \& Lloyd, D. (1975). The preparation of large-scale synchronous cultures of the trypanosomatid, Crithidia fasciculata, by cell-size selection: changes in respiration and adenylate charge through the cell-cycle. Journal of General Microbiology 88, 141-152.

FromM, H. (1977). Control by energy charge is an untenable theory. Trends in Biochemical Sciences 2, N198-N200.

Holm-Hansen, O. (1969). Determination of microbial biomass in ocean profiles. Limnology and Oceanography 14, 740-747.

Kimmich, G. A., Randles, J. \& Brand, J. S. (1975). Assay of picomole amounts of ATP, ADP, and AMP using the luciferase enzyme system. Analytical Biochemistry 69, 167-206.
KNowles, C. J. (1977). Microbial metabolic regulation by adenine nucleotide pools. Symposia of the Society for General Microbiology 27, 241-283.

Lloyd, D., Phillips, C. A. \& Statham, M. (1978). Oscillations of respiration, adenine nucleotide levels and heat evolution in synchronous cultures of Tetrahymena pyriformis ST prepared by continuous-flow selection. Journal of General Microbiology 106, 19-26.

Macleold, N. H., Chapelle, E. W. \& Crawford, A. M. (1969). ATP assay of terrestrial soils: a test of an exbiological experiment. Nature, London 223, 267-268.

Niven, D. F., Collins, P. A. \& Knowles, C. J. (1977). Adenylate energy charge during batch culture of Beneckea natriegens. Journal of General Microbiology 98, 95-108.

Pradet, A. (1967). Étude des adenosines-5'-mono, di et triphosphates dans les tissues végétaux. I. Dosage enzymatique. Physiologie Végétale $\mathbf{5}$, 209-221.

Saglio, P., L'Hospital, M., Lafleche, D., Dupont, G., Bove, J. M., Tully, J. G. \& Freundt, E. A. (1973). Spiroplasma citri gen. and sp.n.: a mycoplasma-like organism associated with 'stubborn' disease of citrus. International Journal of Systematic Bacteriology 23, 191-204.

Saglio, P., Daniels, M. J. \& Pradet, A. (1976). ATP and energy charge as criteria of growth and metabolic activity of Mollicutes: application to Spiroplasma citri. Proceedings of the Society for General Microbiology 3, 155.

SCHRAM, E. (1970). Use of scintillation counters for bioluminescence assay of adenosine triphosphate (ATP). In The Current Status of Liquid Scintillation Counting, p. 129. Edited by E. D. Bransome Jr. New York: Grune and Stratton.

Schramm, V. L. \& LeUNG, H. (1973). Regulation of adenosine monophosphate levels as a function of adenosine triphosphate and inorganic phosphate. A proposed metabolic role for adenosine monophosphate nucleosidase from Azotobacter vinelandii. Journal of Biological Chemistry 248 , 8313-8315.

WINDSOR, R. S. \& BoARER, C. D. H. (1972). A method for rapid enumeration of mycoplasma species growing in broth culture. Journal of Applied Bacteriology 35, 37-42. 